\title{
HYALURONIDASE ACTIVITY IN THE SKIN, RHEUMATIC DISEASE, AND SALICYLATES
}

\author{
BY \\ E. SHERWOOD JONES \\ From the Liverpool School of Tropical Medicine, University of Liverpool
}

This study* was undertaken to ascertain the effect of salicylate on the spreading activity of testicular extract (T.E.) in the human skin, and its relationship to rheumatic disease.

\section{Introduction}

Hyaluronidase.-It was shown by Duran-Reynals (1928) and McClean (1930) that testicular extract would enhance the infection by vaccinia virus. DuranReynals (Hoffman and Duran-Reynals, 1930) further noted that the spread of inert particulate matter (india ink) was enhanced by T.E. In these experiments intradermal injections of T.E. and india ink were made into the shaved skin of rabbits. The wheals which resulted from the injection of T.E. disappeared more rapidly than did the controls of saline and india ink, and the area of spread for the former was greater than for the latter, the maximum spread being reached in one hour. Variations in the histological pictures of the two areas was also noted. This explanation of the enhancing of the spread of infection by T.E. is now generally accepted, and the group of substances which show this phenomenon are referred to as the "spreading factors". The hypothesis of increased permeability of the tissues induced by T.E. was given factual support by Chain and Duthie (1939; 1940). The evidence was put forward that the spreading factors operated by reducing the viscosity of the mucoid ground substance of the connective tissues, and that the spreading factors were, in fact, enzymes. These enzymes reduce the viscosity of hyaluronic acid derived from synovial and ocular fluids, and were therefore termed hyaluronidases. Viscosimetric methods were devised and an accurate assay of the spreading factors could be made under controlled conditions. Hyaluronidase was shown to be thermolabile and susceptible to changes of $p \mathrm{H}$. Testicular extracts have been purified to obtain hyaluronidase in a highly concentrated state. The enzyme can be assayed in vitro by various methods (Chain and Duthie, 1940; Swyer and Emmens, 1947), or biologically in the experimental animal (Madinaveitia, 1938). Hyaluronidases have been extracted from a wide variety of bacteria, including Group A haemolytic streptococci; and in the case of the latter there appears to be some relationship between the production of mucoid capsules, enzymatic activity, and virulence (Meyer, Hobby, and others, 1940).

* Part-time work carried out during the tenure of a B.M.A. Scholarship. 
Hyaluronic Acid.-The term hyaluronic acid was applied (Meyer and Palmer, 1936) to a protein-free polysaccharide composed of glucuronic acid and $\mathrm{N}$-acetylglucosamine in equimolar quantities. It was first isolated from umbilical cord and vitreous humour (Meyer and Palmer, 1936), and later from synovial fluid (Meyer and others, 1939) and mucoid haemolytic streptococci (Meyer, Hobby and others, 1940). A substance closely resembling hyaluronic acid has been isolated from rabbit skin (Chain and Duthie, 1940), pig skin (Meyer and Chaffee, 1941), and human skin (Pearce and Watson, 1949). It is probable, but the evidence is as yet insufficient, that hyaluronic acid and chondroitin sulphuric acid are present in all connective tissues, and that the latter substance (which is also attacked by hyaluronidase) may also exist in the blood vessels, including the capillaries. Methods have been devised to stain the inter-cellular ground substance (Bensley, 1934) of connective tissue, but no histo-chemical stain specific to hyaluronic acid has been evolved.

The inter-action of enzyme and substrate is accompanied by an immediate fall in viscosity, and by liberation of glucuronic acid and $\mathrm{N}$-acetyl-glucosamine.

The literature on hyaluronic acid and hyaluronidase has been subjected to careful review (Duran-Reynals, 1942; Meyer, 1947).

Effects of Hyaluronidase in Skin.-When saline or inactivated T.E. (heated at $60^{\circ} \mathrm{C}$. for 15 minutes) is injected intradermally a bleb is raised which shows an initial pallor and a peau d'orange surface. A volume of $0.2 \mathrm{ml}$. produces a wheal of approximately $10 \mathrm{~mm}$. diameter. The pressure necessary to induce such a wheal is considerable. An intradermal wheal of normal saline persists for about 50 minutes, the wheal disappearance time (W.D.T.) depending on the site of the injection and state of tissue hydraemia (McClure and Aldrich, 1923). The W.D.T. is best observed by viewing the bleb in a horizontal plane and by palpation with a finger-tip. If an indicator (e.g. haemoglobin, trypan blue, Evans blue) is injected intradermally similar observations can be made, excepting that the initial pallor of the wheal is not readily seen. $0 \cdot 2 \mathrm{ml}$. of human haemoglobin in isotonic solution injected intradermally into the ventral aspect of the exposed human forearm produces a bleb which is usually visible and palpable for over one hour. The events which follow the introduction of T.E. into the skin sharply contrast with the foregoing. There is seen a rapid flattening of the injection bleb, which is " characteristic of solutions containing hyaluronidase" (Chain and Duthie, 1940). Further, the pressure required (plunger force) in the case of T.E. rapidly diminishes as the injection proceeds, and the rate of spread over the control is greatly increased. The intradermal injection of $0.2 \mathrm{ml}$. of normal saline, active or inactivated T.E. with, or without, haemoglobin induces in the human skin a roughly circular capillary flush, from 15 to $20 \mathrm{~mm}$. in diameter around the bleb. This reaction to injury shows an individual variation. The activity of hyaluronidase in the skin as judged by the area of dye (indicator) after a given time is proportional to the concentration of enzyme (to a limit) and the interstitial pressure of the injection. Hechter $(1946$; 1947) has shown that there is a lack of correlation between high concentrations of the enzyme and the area of spread, and that the initial rate and 
final area of spreading produced by a constant total amount of hyaluronidase administered in varying volume is directly proportional to the volume of fluid injected intradermally. Hechter (1947) believes that, under physiological conditions, hyaluronidase diffuses through skin at a slow rate by attacking the barrier of hyaluronic acid in its immediate vicinity. This slow process is, under artificial conditions, greatly accelerated by the pressure and volume of the injection. When an area of skin which has been previously " treated " with T.E. is injected with saline there is an increased rate of diffusion of the saline bleb; that is, the W.D.T. is decreased. After an interval of 24 hours, however, saline diffusion in the area is normal. This evidence provided by Hechter (1948) is interpreted by him as showing that the dermal " barrier" of hyaluronic acid, which is broken down by enzymatic activity, is reconstituted within 24 hours. These experiments were made on the adult forearm skin.

It is disputed whether T.E. affects capillary permeability (Duran-Reynals, 1942; Meyer, 1947; Chambers and Zweifach, 1947).

Relationship of Hyaluronidase to other Spreading Factors.-The spreading activity of many inflammatory agents (e.g. trypsin, casein digest, urea) differs from that of hyaluronidase in that it is slower and that the injection bleb persists as spreading takes place. These agents do not show spread in dead skin, whereas hyaluronidase does (McClean, 1931). It was shown that the inflammatory agents did not liberate hyaluronidase already present ("bound ") in the skin (Hechter and Solomon, 1948). It is considered that inflammatory agents induce capillary damage and oedema and thus increase the interstitial pressure in the bleb. The permeability of the dermal barrier need not, therefore, be affected. Snake venoms, urea, peptones (Hechter and Solomon, 1948) and histamine (Swyer, 1948a) enhance the spreading effect of hyaluronidase in proportion to their concentration. Gross changes in capillary permeability may be demonstrated by the leakage of dye circulating in the blood. Swyer (1948a), using pontamine blue in the rabbit, did not observe any effects by hyaluronidase, but positive reactions were noted with histamine and snake venoms, thus revealing the gross changes in capillary permeability wrought by these agents.

Hyaluronidase; Rheumatic Disease; Salicylates.-In 1946 Guerra claimed that sodium salicylate inhibited the spreading activity of T.E. as judged by the diffusion of dye in the skin, and, further, that patients with rheumatic disease showed abnormal reactions to T.E., which were reduced by salicylate. A series of experiments on albino rabbits (1946a) was conducted, using bull-testis hyaluronidase and india ink as an indicator. Salicylate was administered intravenously as sodium salicylate in a 10 per cent. solution, 15 minutes prior to the intradermal test. The areas of skin staining were traced on cellophane and measured, 1 hour and 24 hours after the intradermal injections. He noted that the spread of the T.E. was six times greater than that of the control. The control areas of spread were reduced 20 per cent. by salicylate in dosage of $0.07 \mathrm{~g}$. per kilo bodyweight, and 31 per cent. by $0.1 \mathrm{~g}$. per kilo bodyweight; the T.E. areas of spread were inhibited 57 per cent. and 66 per cent. by salicylate, in dosage of $0.07 \mathrm{~g}$. and $0.1 \mathrm{~g}$. per kilo bodyweight 
respectively. Guerra made further observations (1946b) on 36 normal children and adults. The method was essentially similar to the animal experiments, but Evans blue was used in lieu of the india ink. The areas of spread were measured at the end of 24 hours. An inhibition of T.E. by salicylates of $49 \cdot 5$ per cent. was noted (Guerra and Robles Gil, 1946). In addition, these authors stated that " intradermal injections on individuals, either having active rheumatic fever or having suffered it, give unique reactions with enormous diffusion of the dye and local oedema that sometimes occupies the arm injected with hyaluronidase. The salicylate also inhibits the enzyme in those cases and reduces its spreading effect on connective tissue. These types of allergic reactions to hyaluronidase were also observed in one male suffering from exanthematic typhus". A later study (Robles Gil and Guerra, 1947) was made on six patients with active rheumatoid

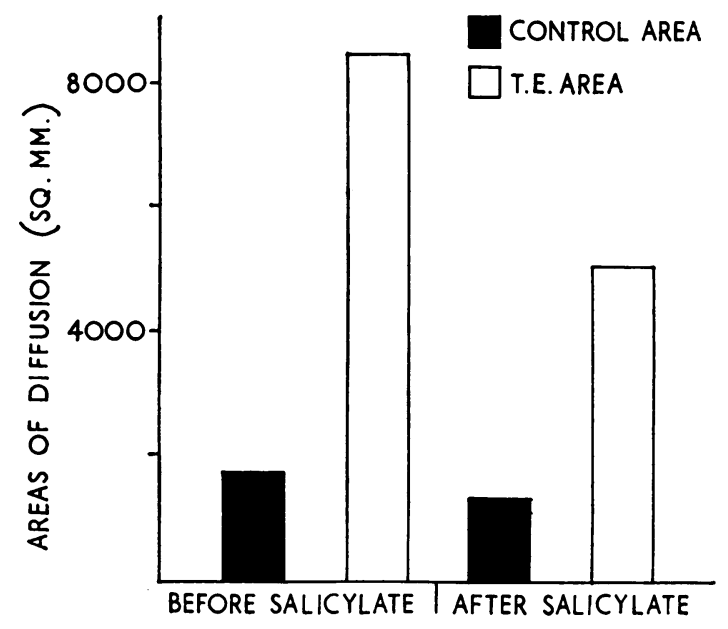

Fig. 1 (after Guerra). Areas of spread of T.E. and Control in patients with rheumatoid arthritis, before and after sodium salicylate. The results in patients with rheumatic fever were essentially similar. arthritis and on twelve cases of active rheumatic fever. Evans blue was again used as indicator, with saline control. Sodium salicylate was administered intravenously 15 minutes prior to the intradermal tests. It was noted (Fig. 1) that the areas of spread of T.E. in the skin in patients with rheumatoid arthritis and rheumatic fever were three to four times greater than the control areas, and that in these conditions the spread of T.E. was greater than in normal subjects. In addition the intravenous administration of sodium

salicylate to patients with rheumatoid arthritis and rheumatic fever inhibited the intradermal spread of T.E. Following the observations of Guerra, Dorfman, and others (1947) claimed that hyaluronidase was inhibited by salicylates both in vivo (in the rabbit) and in vitro, and that the concentration necessary for in vitro inhibition was "considerably higher" than that required in vivo. Accepting this work, the therapeutic value of salicylates in rheumatic disease was reasoned as follows: certain pathogenic streptococci produce hyaluronidase; the connective tissues are dominantly affected in the rheumatic diseases, and contain hyaluronic acid and chondroitin sulphuric acid; hyaluronidase reduces the viscosity of hyaluronic acid and chondroitin sulphuric acid by depolymerization, and thus facilitates the spread of bacteria or their toxins; rheumatic patients are "sensitive" to hyaluronidase; salicylate inhibits the enzymatic action of hyaluronidase and 
is therefore anti-rheumatic. This hypothesis has been elaborated by Guerra (1946a, b), Dry and others (1946), Meyer and Ragan (1948a, b, c), and others.

It was shown, however, that salicylate did not inhibit hyaluronidase in vitro except in very high concentration, when the hydrogen ion concentration of the reaction was seriously affected (Pike, 1947; Swyer, 1948b). Moreover, Guerra's results in the rabbit were not confirmed by Swyer (1948a). Swyer administered sodium salicylate as 10 per cent. $\mathrm{w} / \mathrm{v}$ solution, $0 \cdot 1 \mathrm{~g}$. per kilo bodyweight, 15 minutes prior to the intradermal tests. The results were read after 30 minutes. It was found that salicylate " scarcely " influenced the spreading activity of hyaluronidase. It was further noted that parenteral salicylate inhibited the spreading activity of a hyaluronidase-histamine mixture to that of the hyaluronidase component alone. Salicylate was thus demonstrated to have an anti-histamine effect. Swyer considered his results might imply that contamination of the T.E. used by Guerra with histamine or an allied substance was responsible for the inhibition of hyaluronidase by salicylate claimed by the latter. The contradictory results appear to be reconciled in part by the findings of Lowenthal and Gagnon (1947) and Meyer and Ragan (1948b) that the metabolites of salicylate (Kapp and Coburn, 1942) were inhibitory, both in vivo and in vitro. Gentisic acid, isolated from the urine of patients receiving sodium salicylate, was found to be a potent inhibitor of hyaluronidase in vitro (Meyer and Ragan, 1948b). These authors made the additional claim that synthetic sodium gentisate was anti-rheumatic (1948c).

This brief outline gives little indication of the experimental work and vast literature concerning hyaluronidase and hyaluronic acid. It would appear premature to interpret "allergic" reactions to hyaluronidase or the results of intradermal tests in rheumatic subjects as evidence of an important role by the enzyme in rheumatic disease, and there is not yet sufficient evidence to elucidate the therapeutic action of salicylate. The present position in relation to rheumatic disease has been stated with customary eloquence by Cohen (1949): “It cannot be claimed that as a result of the knowledge thus far attained we stand on the brink of a new era in the understanding of rheumatic disease. Indeed, we cannot as yet assert that any direct association between hyaluronic acid metabolism and rheumatism has been established. The evidence is, however, suggestive and a fruitful field of study has been revealed which merits further exploration. The history of rheumatism is itself the most forceful warning against the uncritical acceptance of hypotheses, however intriguing, alluring, or seductive they might appear. We may mourn the slaughter of a beautiful hypothesis by an uncompromising fact, but the tragedy must unresentfully be accepted."

\section{Observations}

\section{METHODS}

The T.E.* used in the experiments showed considerable activity. One batch of $1 \mathrm{ml}$. ampoules was used throughout and assays in vitro were performed from 
time to time but showed no significant change in activity; typical curves are shown in Fig. 2. The method of Swyer and Emmens (1947) was used. Viscosimetric studies did not reveal any influence of haemoglobin on hyaluronidase activity.

All the injections were made into the ventral aspect of the exposed mid-forearm of human volunteers. Each injection was of a volume of $0.2 \mathrm{ml}$. and made via a 20-gauge short-bevelled needle. The syringes were all-glass $1 \mathrm{ml}$. (Vim 800T). The injections were made approximately $10 \mathrm{~cm}$. apart. The same skin area was never injected on more than one occasion. The control injections were made first and the time-keeper started when the T.E. had been injected. All dilutions were made with sterile normal saline, and when haemoglobin was used as an indicator it was prepared under sterile conditions according to the method of Madinaveitia (1938). Hyaluronate for assay was prepared according to McClean and Williams (1943). One experiment only was performed on each subject. The area of spread was read at 1 hour by tracing the haemoglobin diffusion on cellophane strapped to the skin. The cellophane was then adfixed to $\mathrm{mm}$. squared paper with transparent cement and the squares counted (Guerra, 1946a).

Blood was drawn from the patient immediately prior to intradermal tests, and the serum salicylate estimated according to the method of Volterra and Jacobs (1947).

\section{RESULTS}

Normal Subjects.-In the initial experiments attempts were made to utilize the flattening of an intradermal wheal (wheal disappearance time) of T.E. as a measure of hyaluronidase activity, thus obviating the need for an indicator.

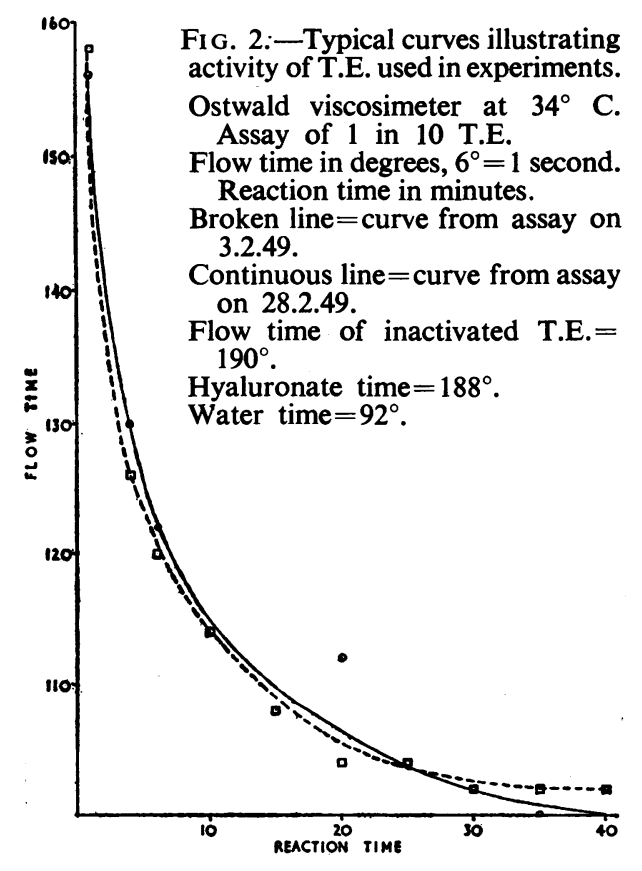

It will be seen from Table I that with T.E. diluted 1 in 2 the bleb was no longer visible or palpable after 1 minute, and that with T.E. diluted 1 in 10 in normal saline the W.D.T. was approximately 5 minutes. At this time the control wheals of saline and inactivated T.E. were readily visible and palpable. The diameters of the blebs did not change significantly, the principal reaction being a reduction in thickness in the case of T.E.

Experience showed, however, that the W.D.T. was difficult to determine near its end-point, and in consequence an indicator was employed. 1 per cent. trypan blue in normal saline was employed for a time, but the permanent staining left by this dye was considered undesirable; haemoglobin was therefore decided upon. 
TABLE I

MEAN DIAMETERS OF WHEALS AND WHEAL DISAPPEARANCE TIMES IN SIX NORMAL SUBJECTS

\begin{tabular}{|c|c|c|c|c|c|c|c|}
\hline & & & & \multicolumn{2}{|c|}{ Time } & & \\
\hline & & \multicolumn{2}{|c|}{ Zero } & \multicolumn{2}{|c|}{ One minute } & \multicolumn{2}{|c|}{ Five minutes } \\
\hline & & $\begin{array}{c}\text { Right } \\
\text { arm }\end{array}$ & $\begin{array}{l}\text { Left } \\
\text { arm }\end{array}$ & $\begin{array}{c}\text { Right } \\
\text { arm }\end{array}$ & $\begin{array}{l}\text { Left } \\
\text { arm }\end{array}$ & $\begin{array}{c}\text { Right } \\
\text { arm }\end{array}$ & $\begin{array}{l}\text { Left } \\
\text { arm }\end{array}$ \\
\hline \multirow{3}{*}{ (a) } & $\mathbf{X}$ & & & ++ & ++ & ++ & ++ \\
\hline & $\mathbf{Y}$ & 10 & $9 \cdot 5$ & $10 \cdot 5$ & $9 \cdot 5$ & $10 \cdot 5$ & $9 \cdot 5$ \\
\hline & $\mathbf{Z}$ & 9 & 8 & 9 & $8 \cdot 5$ & 9 & $9 \cdot 5$ \\
\hline \multirow{3}{*}{ (b) } & $\mathbf{X}$ & & & ++ & ++ & ++ & ++ \\
\hline & $\mathbf{Y}$ & 9 & 10 & 10 & 9 & 9 & 11 \\
\hline & $\mathbf{Z}$ & 8 & 9 & 8 & 8 & 9 & 9 \\
\hline \multirow{3}{*}{ (c) } & $\mathbf{X}$ & & & ++ & ++ & ++ & ++ \\
\hline & $\mathbf{Y}$ & 8 & 8 & 8 & 9 & 9 & 9 \\
\hline & $\mathbf{Z}$ & 8 & $7 \cdot 5$ & 8 & 8 & 8 & 8 \\
\hline \multirow{3}{*}{ (d) } & $\mathbf{x}$ & & & $8+$ & $10+$ & ++ & ++ \\
\hline & y & 8 & 10 & 9 & 10 & 10 & 10 \\
\hline & $\mathbf{z}$ & 8 & 10 & 8 & 10 & 9 & 10 \\
\hline \multirow{3}{*}{ (e) } & $\mathbf{x}$ & & & $9 \cdot 5$ & $10+$ & ++ & ++ \\
\hline & y & $8 \cdot 5$ & 10 & $9 \cdot 5$ & 10 & 10 & $10 \cdot 5$ \\
\hline & $\mathbf{z}$ & 9 & 10 & 9 & $10 \cdot 5$ & 10 & $10 \cdot 5$ \\
\hline \multirow{3}{*}{ (f) } & $\mathbf{x}$ & & & ++ & ++ & ++ & ++ \\
\hline & $\mathbf{y}$ & 10 & 9 & 11 & $9 \cdot 5$ & 11 & $9 \cdot 5$ \\
\hline & $z$ & 10 & $8 \cdot 5$ & 11 & $8 \cdot 5$ & 11 & $8 \cdot 5$ \\
\hline
\end{tabular}

$\mathrm{X}=0.2 \mathrm{ml}$. T.E. diluted 1 in 2 . Injected third.

$Y=0.2 \mathrm{ml}$. inactivated 1 in 2 T.E. Injected second.

$\mathrm{Z}=0.2 \mathrm{ml}$. normal saline. Injected first.

$\mathbf{x}=0.2 \mathrm{ml}$. T.E. diluted 1 in 10 . Injected third.

$y=0.2 \mathrm{ml}$. inactivated 1 in 10 T.E. Injected second.

$\mathrm{z}=0.2 \mathrm{ml}$. normal saline. Injected first.

$+=$ Flattening of the intradermal wheal.

$++=$ Complete flattening of the intradermal wheal.

Table III (page 145) shows the results of an experiment carried out on nine healthy medical students before and after salicylate administration. The 28 injections were divided into four groups and each group received a freshly-prepared solution of T.E. and haemoglobin. $0.1 \mathrm{ml}$. of T.E., diluted 1 in 5 with normal saline plus $0.1 \mathrm{ml}$. of 
isotonic haemoglobin solution, was injected $10 \mathrm{~cm}$. from a control intradermal injection (C), consisting of $0.1 \mathrm{ml}$. normal saline plus $0.1 \mathrm{ml}$. of haemoglobin solution. The injections were distributed as shown in Table II, and the areas of spread were measured at 1 hour. The procedure was repeated a week later, 4 hours after the oral exhibition of $6 \mathrm{~g}$. of sodium salicylate. The serum concentrations of salicylate are seen (Table III) to vary from 16 to $53 \mathrm{mg}$. per cent. The areas of skin staining show significant individual variation, as noted in the rabbit by Swyer (1948a). When consideration is given to the numerous factors which influence the technique it cannot be concluded that salicylate inhibits the intradermal spread of T.E.

Abnormal Reaction.-The nine cases recorded in Table I were members of a group of ten medical students, one of whom (No. 8) showed an abnormal reaction. Enquiry disclosed a previous history of serum sickness. Four to 5 minutes after the intradermal injection of T.E. incomplete flattening of the wheal was noted. This was accompanied by the formation of pseudopodia around the control injection and a "re-growth" of the T.E. wheal. Both wheals showed abnormal pallor and were surrounded by a marked capillary flush. At 1 hour both wheals were flat, but the area they had occupied was discernible because of its pallor; the capillary flush was fading. No haemoglobin was visible. The reaction was

TABLE II

DISTRIBUTION OF INJECTIONS IN TEN NORMAL SUBJECTS

\begin{tabular}{|c|c|c|c|c|c|}
\hline \multirow[t]{2}{*}{ Case } & \multirow[t]{2}{*}{ Arm } & \multicolumn{2}{|c|}{ Before salicylate } & \multicolumn{2}{|c|}{ After salicylate } \\
\hline & & Distal & Proximal & Distal & Proximal \\
\hline \multirow{2}{*}{1,7} & $\mathbf{R}$. & & & T.E. & C. \\
\hline & L. & C. & T.E. & & \\
\hline \multirow{2}{*}{2} & R. & & & C. & T.E. \\
\hline & L. & T.E. & C. & & \\
\hline \multirow{2}{*}{3,8} & R. & C. & T.E. & & \\
\hline & L. & & & T.E. & C. \\
\hline \multirow{2}{*}{4,9} & $\mathbf{R}$. & T.E. & C. & & \\
\hline & L. & & & C. & T.E. \\
\hline \multirow{2}{*}{5,10} & R. & & & C. & T.E. \\
\hline & L. & C. & T.E. & & \\
\hline \multirow{2}{*}{6} & $\mathbf{R}$. & T.E. & C. & & \\
\hline & L. & & & T.E. & C. \\
\hline
\end{tabular}

Distal and Proximal refer to the placing of the injections, which were $10 \mathrm{~cm}$. apart on the ventral aspect of the forearm skin. 
TABLE III

RESULTS OF EXPERIMENTS ON NINE NORMAL SUBJECTS

\begin{tabular}{|c|c|c|c|c|c|c|c|}
\hline \multirow[b]{2}{*}{ Case No. } & \multicolumn{3}{|c|}{ Before salicylate } & \multicolumn{4}{|c|}{ After salicylate } \\
\hline & C.A. & $\begin{array}{l}\text { W.D.T. } \\
\text { of T.E. }\end{array}$ & T.E.A. & $\begin{array}{c}\text { Serum } \\
\text { salicylate } \\
\text { mg. } \\
\text { per cent. }\end{array}$ & C.A. & $\begin{array}{l}\text { W.D.T. } \\
\text { of T.E. }\end{array}$ & T.E.A. \\
\hline 1 & 266 & 10 & 612 & 47 & 305 & 28 & 466 \\
\hline 2 & 300 & 10 & 561 & 53 & 334 & $7 \cdot 5$ & 527 \\
\hline 3 & 222 & 5 & 648 & 26 & 241 & 9 & 543 \\
\hline 4 & 191 & 5 & 731 & 29 & 228 & 18 & 678 \\
\hline 5 & 282 & 8 & 582 & 32 & 239 & 3 & 568 \\
\hline 6 & 305 & 9 & 811 & 16 & 273 & 7 & 758 \\
\hline 7 & 212 & 6 & 408 & 50 & 213 & 14 & 376 \\
\hline 9 & 354 & 11 & 794 & 30 & 435 & 10 & 1,312 \\
\hline 10 & 213 & 10 & 983 & 30 & 276 & 10 & 1,336 \\
\hline
\end{tabular}

C.A. $=$ Control Area, i.e. stained area in sq. mm., at one hour.

W.D.T. = Wheal Disappearance Time, in minutes.

T.E. = Testicular Extract.

T.E.A. = Testicular Extract Area, i.e. stained area in sq. mm., at one hour.

judged to be similar before and after the administration of sodium salicylate. The serum concentration at the time of the injections was $28 \mathrm{mg}$. per cent., which is an adequate therapeutic level. The abnormal reaction was comparable to the changes brought about by the intradermal injection of histamine acid phosphate. This allergic response was demonstrated to have a non-specific origin by performing intradermal tests on five cases of allergic asthma and hay-fever. In four cases an allergic reaction was observed, qualitatively identical to that described above. The five patients showed no reaction to intradermal saline.

TABLE IV

TYPES OF RHEUMATIC DISEASE IN EIGHT SUBJECTS

\begin{tabular}{c|l}
\hline Case & \multicolumn{2}{c}{ Disease } \\
\hline 11 & Active rheumatic fever. First attack. Pan-carditis and nodules \\
\hline 12 & Purpura rheumatica. No cardiac signs. \\
\hline 13 & Active rheumatic fever. Second attack \\
\hline 14 & Active rheumatic fever. Mitral and aortic disease \\
\hline $15-18$ & Active generalized rheumatoid arthritis of 6 months' to 7 years' duration \\
\hline
\end{tabular}


TABLE V

RESULTS OF EXPERIMENTS ON FOUR RHEUMATIC SUBJECTS

\begin{tabular}{|c|c|c|c|c|c|c|c|c|c|}
\hline \multirow[b]{2}{*}{ Case No. } & \multicolumn{4}{|c|}{ Before salicylate } & \multicolumn{5}{|c|}{ After salicylate } \\
\hline & C.A. & $\begin{array}{l}\text { W.D.T. } \\
\text { of T.E. }\end{array}$ & T.E.A. & $\begin{array}{l}\text { Allergic } \\
\text { reaction }\end{array}$ & $\begin{array}{l}\text { Serum } \\
\text { salicylate } \\
\text { mg. } \\
\text { per cent. }\end{array}$ & C.A. & $\begin{array}{l}\text { W.D.T. } \\
\text { of T.E. }\end{array}$ & T.E.A. & $\begin{array}{l}\text { Allergic } \\
\text { reaction }\end{array}$ \\
\hline 11 & 189 & 16 & 469 & none & $36 \cdot 6$ & 180 & 14 & 657 & none \\
\hline 12 & 186 & & & ++ & & & & & \\
\hline 13 & 159 & 12 & 781 & + & $20 \cdot 0$ & 125 & 15 & 670 & + \\
\hline 14 & 271 & 18 & 863 & + & $13 \cdot 0$ & 320 & 8 & 801 & + \\
\hline
\end{tabular}

C.A. = Control Area, i.e. stained area in sq. mm., at one hour.

W.D.T. = Wheal Disappearance Time, in minutes.

T.E. = Testicular Extract.

T.E.A. = Testicular Extract Area, i.e. stained area in sq. mm., at one hour.

Patients with Rheumatic Disease.-Intradermal tests were performed on eight cases of rheumatic disease, detailed in Table IV. The T.E. and control injections used were identical with those employed in the normal subjects, and the injections were distributed in a manner similar to that shown in Table II. The " after salicylate" results refer to intensive and continuous salicylate therapy. The results are summarized in Tables $\mathrm{V}$ and VI. Three of the four cases of rheumatic fever gave an allergic reaction; in case No. 12 this was sufficiently marked to prevent the estimation of the W.D.T. and of the area of spread of T.E. The skin staining at the end of 1 hour for T.E. in case No. 12 was over a wide area (approximately 1,500 sq. $\mathrm{mm}$.), but the faintness of colouration and marked capillary flush made accurate measurement impossible. The areas of spread of T.E. in those cases of rheumatic fever or rheumatoid arthritis who showed no allergic reaction were not significantly different from the areas of skin staining in normal subjects. In three of the cases of rheumatic fever there was no evidence that salicylate inhibited the intradermal spread of T.E.

\section{Summary}

(1) A study of the literature leads to the opinion that there is insufficient information to incriminate hyaluronidase as an important factor in the pathogenesis 
of rheumatic disease. Nor can it be concluded that the experimental evidence so far accumulated explains the anti-rheumatic effect of salicylates.

(2) The results of intradermal tests on eighteen humans is presented. Bulltestis hyaluronidase, with haemoglobin as an indicator, was employed. The area of spread of testicular extracts in the skin of nine healthy medical students and of three cases of rheumatic fever was not influenced by the administration of sodium salicylate. In one person, who gave a history of serum sickness, and in three cases of rheumatic fever, there was allergic reaction; a similar reaction was observed in five cases of allergic asthma. The areas of spread of testicular extract in those cases of rheumatic fever or rheumatoid arthritis who show no allergic reaction are not significantly different from the areas of skin staining in normal subjects.

I am greatly indebted to Professor Brian Maegraith for guidance and for the most generous laboratory facilities. Dr. G. I. M. Swyer gave helpful criticism and Mr. R. L. Plackett statistical advice. Dr. D. Riding, Director of the Evans Biological Institute, kindly supplied the hyaluronidase and haemoglobin solutions.

\section{REFERENCES}

Bensley, S. H. (1934). Anat. Rec., 60, 93.

Chain, E., and Duthie, E. S. (1939). Nature, 144, 977.

- - (1940). Brit. J. exp. Path., 21, 324.

Chambers, R., and Zweifach, B. W. (1947). Physiol. Rev., 27, 436.

Cohen, H. (1949). Annals of the Rheumatic Diseases, 8, 31 .

Dorfman, A., Reimers, E. J., and Ott, M. L. (1947). Proc. Soc. exp. Biol., 64, 357.

Dry, T. J., Butt, H. R., and Scheifley, C. H. (1946). Proc. Mayo CKn., 21, 497.

Duran-Reynals, F. (1928). C.R. Soc. Biol. Paris, 99, 6.

- (1942). Bact. Rev., 6, 197.

Guerra, F. (1946a). J. Pharmacol., 87, 193.

- (1946b). Science, 103, 686.

, and Robles Gil, J. (1946). Arch. Inst. Cardiol. Méx., 6, 293.

Hechter, O. (1946). Science, 104, 409.

- (1947). J. exp. Med., 85, 77.

- (1948). Proc. Soc. exp. Biol., 67, 343.

-, and Solomon, S. (1948). Nature, 162, 701.

Hoffman, D. C., and Duran-Reynals, F. (1930). Science, 72, 508.

Kapp, E. M., and Coburn, A. F. (1942). J. Biol. Chem., 145, 549.

Lowenthal, J., and Gagnon, A. (1947). Science, 105, 619.

Madinaveitia, J. (1938). Biochem. J., 32, 1806.

McClean, D. (1930). J. Path. Bact., 33, 1045.

- (1931). Ibid., 34, 459.

, Rogers, H. J., and Williams, B. W. (1943). Lancet, 1, 355.

McClure, W. B., and Aldrich, C. A. (1923). J. Amer. med. Ass., 81, 293.

Meyer, K., and Palmer, J. W. (1936). J. biol. Chem., 114, 689.

-, Smyth, E. M., and Dawson, M. H. (1939). Ibid., 128, 319.

-, Hobby, G. L., Chaffee, E., and Dawson, M. H. (1940). J. exp. Med., 71, 137.

- , and Chaffee, E. (1940). J. biol. Chem., 133, 83.

- - (1941). Ibid., 138, 491.

- (1947). Physiol. Rev., 27, 335.

—-, and Ragan, C. (1948a). Mod. Concepts cardiovascular Dis., 17, 2.

-, - (1948b). Fed. Proc., 7, 173.

- - - (1948c). Science, 108, 281.

Pearce, R. H., and Watson, E. M. (1949). Canad. J. Research, 27, Sect. E, 43.

Pike, R. M. (1947). Science, 105, 391.

Robles Gil, J., and Guerra, F. (1947). Arch. Inst. Cardiol. Méx., 7, 733.

Swyer, G. I. M. (1948a). Biochem. J., 42, 28, 32.

, and Emmens, C. W. (1947). Ibid., 41, 29.

Volterra, M., and Jacobs, M. D. (1947). J. Lab. clin. Med., 32, 1282. 
Activité de l'Hyaluronidase dans la Peau; Maladie Rhumatismale et les Salicylates

RÉSUMÉ

(1) L'étude de la littérature nous mène à la conclusion que nos renseignements concernant l'hyaluronidase ne sont pas suffisants pour pouvoir dire que celle-ci constitue un facteur important dans la pathogénèse de la maladie rhumatismale. On ne peut pas conclure, non plus, que les preuves expérimentales accumulées jusqu'à présent expliquent l'effet anti-rhumatismal des salicylates.

(2) On présente ici les résultats des épreuves intradermiques sur 18 sujets humains. L'hyaluronidase des testicules de taureau fut utilisée, l'hémoglobine servant d'indicateur. La diffusion intradermique des extraits testiculaires chez neuf étudiants en médecine sains et dans trois cas de rhumatisme articulaire aigu ne fut pas influencée par l'administration du salicylate de soude. Chez une personne avec une histoire d'accidents sériques et dans trois cas de rhumatisme articulaire aigu il y eut une réaction allergique; une réaction semblable fut observée dans cinq cas d'asthme allergique. A part ceux qui avaient présenté des réactions allergiques, on n'observa aucune différence significative entre les sujets atteints du rhumatisme articulaire aigu ou de l'arthrite rhumatismale et les sujets normaux en ce qui concerne la diffusion de l'extrait testiculaire, indiquée par l'étendue de la surface de la peau colorée.

\section{Actividad de la Hialuronidase en la Piel; Enfermedad Reumática y los Salicilatos \\ RESUMEN}

(1) El estudio de la literatura nos lleva a la conclusión que no hay datos suficientes para poder incriminar la hialuronidase como factor importante en la patogenesis de la enfermedad reumática. Tampoco se puede afirmar que los datos experimentales recogidos hasta le fecha aclaren el efecto anti-reumático de los salicilatos.

(2) Presentamos aquí los resultados de los ensayos experimentales sobre 18 sujetos humanos. Se empleó la hialuronidase de los testículos de torro con hemoglobina como indicadora. La administración de salicilatos no tuvo influencia alguna sobre la difusión intradérmica del extracto testicular en neuve estudiantes de medicina y en tres casos de reumatismo articular agudo. En una persona con historia de enfermedad sérica y en tres casos de reumatismo articular agudo hubo una reacción alérgica; se observó reacción semejante en cinco casos de asma alérgica. A excepción de los que habían presentado reacciones alérgicas no se vió diferencia significativa entre los sujetos sufriendo del reumatismo articular agudo o de la artritis reumatoide y los sujetos normales respecto a la difusión del extracto testicular indicada por el área de la piel coloreada. 